\title{
The Role and Value of Water in Natural Capital Restoration on the Agulhas Plain ${ }^{1}$
}

\author{
Helanya Fourie \\ Western Cape Department of Agriculture, Programme: Agricultural Economics \\ Martin P De Wit \\ School of Public Leadership, Stellenbosch University; ASSET Research
}

A Van der Merwe

Department of Economics, Stellenbosch University

Accepted: August 2012

\begin{abstract}
The Agulhas Plain is a low-lying coastal area within the Cape Floristic Region. It is heavily invaded by alien vegetation that infringes upon the sustainable supply of ecosystem goods and services provided by the native fynbos vegetation. Alien clearing and natural capital restoration is expected to recover these ecosystem goods and services and in particular to increase water availability. The study conducts costbenefit analyses to assess whether alien clearing and natural capital restoration would add value to the Agulhas Plain through sufficiently increasing the supply of marketable ecosystem goods and services. The results indicate that the costs of alien clearing and restoration cannot be justified in the absence of water as a valued commodity. Other ecosystem goods and services included have a negligible impact on justifying costs.
\end{abstract}

Key words: invasive vegetation, water and cost-benefit analysis

JEL: Q56, 57

1

\section{Introduction}

By reducing the resilience of indigenous biodiversity and ecosystems, invasive vegetation threatens the sustainable supply of ecosystem goods and services. The extent of the damage caused by invasive vegetation is illustrated in a report prepared for the Global Invasive Species Programme which found that invasive species impact on 33 per cent of threatened birds, 16 per cent of threatened mammals, and 28 per cent of threatened amphibians (Butchart, Chanson \& Hoffmann, 2009). Climate change is expected to further worsen these impacts (Perrings, Mooney \& Williamson, 2010).

Invasive vegetation is as much an economic as an ecological phenomenon: it occurs as a result of economic activity and economic incentives can contribute towards its control. Valuing the impact of invasive species requires an interdisciplinary approach that draws from an understanding of the ecological and hydrological processes that drive and are in turn influenced by invasive vegetation.

The economic impact of invasive species is determined by the ecosystem in question and the related ecosystem goods and services (Perrings et al., 2010). Valuation studies of ecosystem goods and services have become routine (Van Wilgen, Cowling \& Burgers, 1996; Loomis, Kent, Strange, Fraser \& Covich, 2000; Ricketts, Daily, Ehrlich \& Michener, 2004) with some studies focussing specifically on the costs inflicted by invasive species in South Africa (De Wit, Crookes \& Van Wilgen, 2001; Marais $\&$ Wannenburgh, 2008). Estimating the value of these impacts allows decision-makers to evaluate project investments aimed at clearing invasive species and restoring natural vegetation. The economic return of such projects is determined by the direct project costs and the value of the affected ecosystem goods and services. 
This study tests the hypothesis that through its impact on ecosystem goods and services, invasive vegetation leads to a reduction in the economic value of natural capital at a micro level. It further argues that by investing in the clearing of invasive species and the restoration of indigenous vegetation, value can be restored to an area through increasing the supply of marketable ecosystem goods and services. The study employs cost-benefit analyses to assess the change in marketable ecosystem goods and services brought about by clearing invasive species and restoring natural capital. It places a specific focus on water as a determinant of the economic efficiency of clearing and restoration projects in the Agulhas Plain. To this end the study is arranged as follows: section 2 provides an overview of the literature on natural capital, the occurrence and management of invasive vegetation, economic complexities and markets for ecosystem goods and services. Section 3 introduces the Agulhas Plain. Section 4 describes the model, while section 5 provides a discussion of the results. Section 6 concludes with some policy recommendations.

\section{2}

\section{Natural capital, invasive vegetation and associated economics}

Ecosystem goods and services are particular features of natural capital on which humans rely for survival. Daly (1994) defines natural capital as 'the stock which produces the flux of natural resources: the population of fishes in the ocean generating the flux of fish going to the market; the forest gathering timber; the oil reserves whose exploitation provide petrol'. Daly is correct in regarding natural capital as those features of the environment that support human life, but his definition can be augmented to include ecological systems such as photosynthesis processes, the atmosphere and water cycles (Chiesura \& Groot, 2003; Blignaut \& De Wit, 2004) without which the stocks to which he refers cannot be maintained.

Ecosystem goods and services are often characterised by open access and lack of property rights, rendering individuals reluctant to invest in goods or services from which other users cannot be barred. This results in an absence of markets and prices that are below the actual value of the good or service. Commercial exploitation adds to the pressure, with deforestation as an apt example: as the demand for timber and fuel wood rises, carbon sequestration as one of the ecosystem services provided by trees is affected with detrimental effects to the climate of the planet.

In addition to the unsustainable consumption of ecosystem goods and services, invasive vegetation further threatens their production by damaging the resilience of indigenous ecosystems. Initial research on the subject was driven by the impact that invasive vegetation has on agriculture, but loss in biodiversity and the disturbance of ecosystem services, water supply in particular, has also attracted the attention of researchers (Le Maitre, Van Wilgen, Chapman \& McKelly, 1996; Le Maitre, Versveld \& Chapman, 2000; Mooney \& Cleland, 2001; Carey, 2007; Wilcove, Rothstein, Dubow, Phillips \& Losos, 1998).

Biological invasion results from the deliberate introduction of alien species or their unintentional displacement as a consequence of cross-border activity (Perrings, Williamson, Barbier, Delfino, Silvana, Shogren, Simmons \& Watkinson, 2002). Global trade has been closely linked to the increase in the occurrence of invasive vegetation (Turpie, 2004; Levine \& D'Antonio, 2003), and Bright (1999) has gone so far as to label invasive vegetation as a disease caused by globalisation.

Controlling the spread of invasive species requires '[limiting] the number of plant propagules in the long term to a level [that is] tolerable to human activities' (Groves, 1989), allowing the supply of natural capital to be maintained and to continue to provide a sustainable supply of ecosystem goods and services. The impact of invasive vegetation can be mitigated through passively or actively restoring eroded natural capital. Passive restoration refers to the removal of invasive species and leaving the veld to fend for itself, while active restoration entails direct participation in the recovery of the area. Successful restoration often requires active participation, especially in landscapes where indigenous species are unable to compete with re-sprouting alien plants, or where indigenous vegetation needs to be reintroduced to the area.

Evaluating whether the removal of invasive 
vegetation and the active restoration of natural capital is a value adding endeavour at a systems level depends on the direct and indirect costs and benefits incurred. This requires a valuation of the ecosystem goods and services affected by alien vegetation, described as an attempt to determine the relationship between the underlying ecosystem and the overarching economy (Aylward \& Barbier, 1992). The lack of efficient prices whereby changes in the quantity or quality of an ecosystem good or service can be valued often calls for using shadow prices or other proxies to estimate the value of ecosystem goods and services (Blignaut \& Lumby, 2004). A shadow price can be defined as 'the opportunity cost of products and services when the market price ... does not reflect these costs in full' (Mullins, Mosaka, Green, Downing \& Mapekula, 2007). On occasion when a market for ecosystem goods and services does exist but the mechanism responsible for setting the price is influenced by distortive taxes, subsidies, quotas or tariffs, the price will not reflect the efficient price and will need to be adjusted for these distortions.

\section{3}

\section{Study area: The Agulhas Plain, Cape Floristic Region}

The Cape Floristic Region (CFR) spans 94000 $\mathrm{km}^{2}$ at the southern tip of the African continent. It is home to such a variety of fynbos species that it has been classified as 'one of the hottest' global biodiversity hotspots (Myers, 1990). Of the approximately 8500 fynbos species, 68.2 per cent are endemic, causing Cape Flora to be acclaimed as one of the six plant kingdoms of the world (Higgens, Turpie, Costanza, Cowling, Le Maitre, Marais \& Midgley, 1997).

The fynbos biome supplies a large array of ecosystem goods and services, including fynbos flowers and other fynbos products, ecotourism, and water cycling from mountain catchments. Turpie, Heydenrych and Lamberth (2003) estimate that the use (marketed and nonmarketed) and existence value of the terrestrial and coastal marine biodiversity of the Cape Floristic Region amount to R10 000 million per annum, equivalent to 10 per cent of the gross geographic product of the Western Cape.
The Agulhas Plain is a low-lying coastal region that comprises $2160 \mathrm{~km}^{2}$ within the CFR, as illustrated in Figure 1. It is home to fynbos and renosterveld vegetation, both fireprone shrubland vegetation types that thrive in the Mediterranean climate of the area (Cowling \& Holmes, 1992; Rouget, 2003).

The Agulhas Plain hosts four inland towns: Stanford, Napier and Bredasdorp and Elim, as well as five coastal towns: Gansbaai, Pearly Beach, Agulhas, Struisbaai and Arniston. Most of the land on the Agulhas Plain is under private ownership and used for commercial agriculture, of which livestock grazing covers close to 50 per cent and fynbos farms account for a further 28 per cent (Heydenrych, 1999). Nine percent of the area is under conservation in nature reserves such as the Agulhas National Park, Quine Point Nature Reserve and De Mond Nature Reserve. The majority of the remaining portion of land is dryland pastures dedicated to wheat and barley production (Conradie, 2010).

The Agulhas Plain is covered by five fynbos vegetation types: Mountain fynbos, Strandveld fynbos, Grassy fynbos, Elim fynbos, and Limestone fynbos (Low \& Rebelo, 1996). The fynbos ecosystem of the Agulhas Plain produces a number of products that are traded in both the formal and the informal sector, of which the flower market is the most prominent. The production systems of flower farms on the Agulhas Plain vary between farms that rely on harvesting flowers from the wild, farms that focus on flower cultivation, and a small group of farms on which a combination of the two methods are employed. The increase in demand for fynbos flowers has led to an increase in flower cultivation (Conradie \& Knoesen, 2009).

The fynbos ecosystem also produces other marketable products, such as Honeybush tea, thatching reed and sour figs, and supports the beekeeping and honey production industry by providing foraging for bees. Honeybush tea is made from species of Cyclopia (Heydenrych, 1999) and is mostly harvested from Mountain fynbos, while thatching reed (Thamnochortus insignis) is harvested from Limestone fynbos. Non-landowners in particular draw benefit from Strandveld fynbos from which they harvest sour figs used for making sour fig jam. 


\section{Figure 1}

Location of the Agulhas Plain, Western Cape (Nowell, 2010)

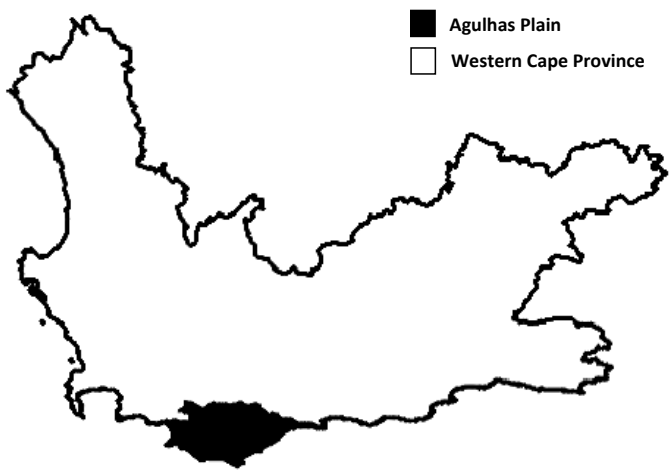

Invasive species constrain the production of ecosystem goods and services provided by fynbos vegetation by restricting its growth or by causing changes in the cycles and intensity of fires. This study considers the three most dominant invasive tree species on the Agulhas Plain: Acacia, Eucalyptus and Pinus. Acacia Cyclops trees (commonly known as Rooikrans) were initially introduced as dune stabilisers and to provide protection (see Figure 2), while Eucalyptus species were introduced in the 1940s with the purpose of providing timber. Pinus species became established through plantations and were also planted to provide tree cover in shrublands (Richardson, 1998). Today, invasive species still provide benefits: many rural households rely on Acacia Cyclops invasions in Strandveld and Lime fynbos as a source of fuel for heating and cooking (Turpie, Heydenrych \& Lamberth, 2003), while Eucalyptus trees provide a valuable source of pollination for bees.

Figure 2

Insert from the Agricultural Journal (Bencke, 1908)

\begin{tabular}{|c|}
\hline 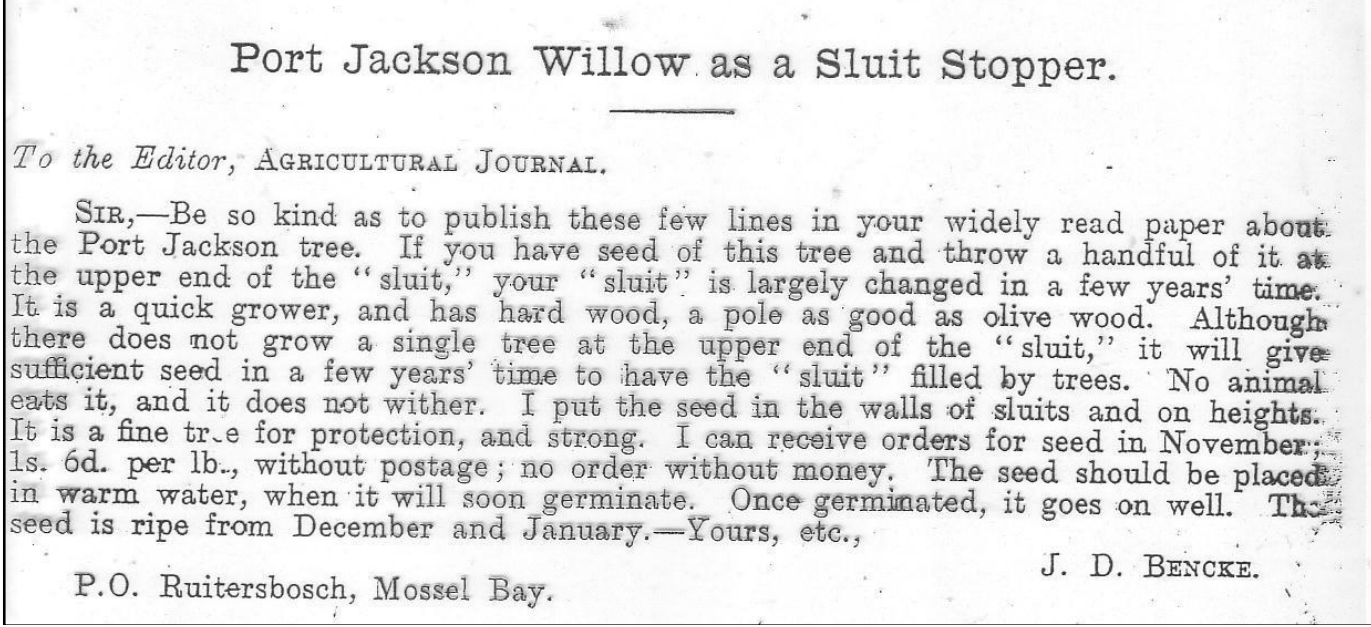 \\
\hline
\end{tabular}

The fynbos biome is the most heavily invaded biome in South Africa (Richardson, MacDonald, Hoffman \& Henderson, 1997; Henderson, 2007). Cole, Lombard, Cowling, Euston-Brown, Richardson and Heijnis (2000) estimated that
14 per cent of Agulhas Plain was invaded with a density of above 50 per cent. In more recent work, Nowell (2010) found that this figure had increased to 31 per cent. The high degree of plant endemism, limited water supply and the 
prevalence of invasive species render the Agulhas Plain a priority area for restoration.

\section{4}

\section{Method and approach}

Cost-benefit analysis provides an instrument that can be used to assess the efficiency of projects dedicated to the clearing of invasive species and restoring natural capital under varying assumptions. An efficient outcome of a clearing and restoration project requires that the value of ecosystem goods and services replaced by restoration at least equals the direct project costs.

The project adopts a time frame of twenty years, based on the assumption that this is a sufficient period for changes within the ecosystem to occur, while simultaneously providing a realistic timeframe under which landowners can plan and be held accountable for land-use decisions. This study assumes postrestoration land-use activities that will ensure a stable supply of ecosystem goods and services. Following Marais and Wannenburgh (2008) and Currie, Milton and Steenekamp (2009), the study tests the impact of a range of low yet positive discount rates in the results of the project.

Ecosystem goods and services included in the model are selected according to the expected impact of alien removal and fynbos restoration on their supply, the accuracy with which changes in their supply can be valued, and whether they can be captured in a market. The model includes wildflowers and fynbos products, water supply, beekeeping, and fuel wood in the analysis, with 2010 prices used throughout. Figure 3 provides a schematic representation of the most prominent marketable ecosystem goods and services affected by alien removal and restoration.

Figure 3

Ecosystem goods and services affected by clearing invasive vegetation and restoring fynbos on the Agulhas Plain (Adapted from Blignaut \& Lumby, 2004)

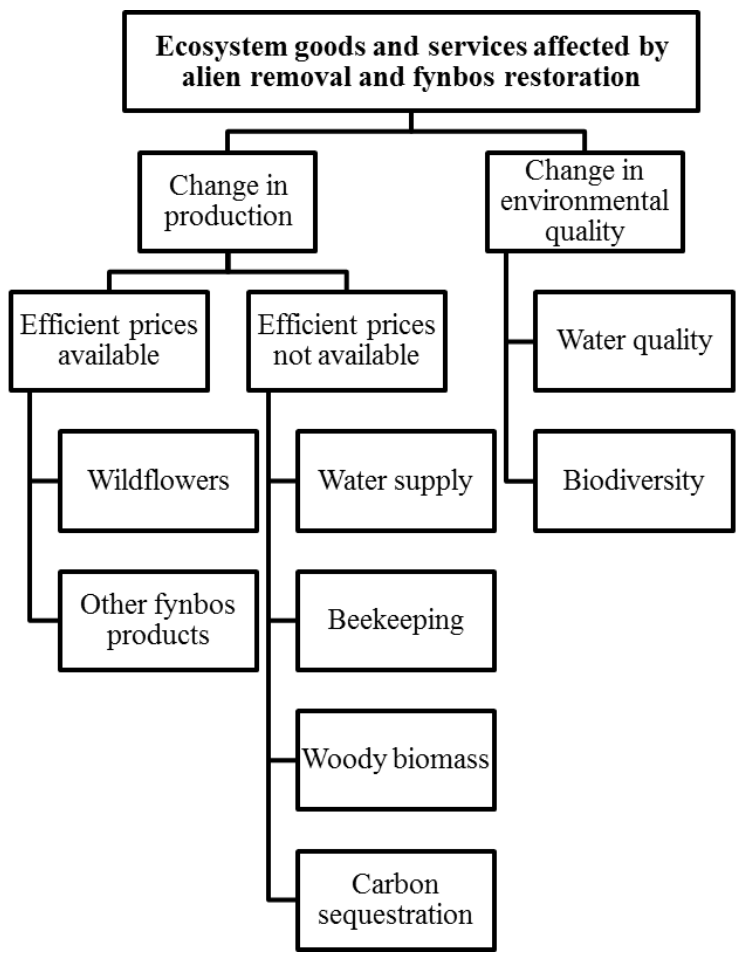


Changes in biodiversity (often valued through ecotourism) are not included in the model due to the supposition that additional fynbos vegetation will have a negligible impact on the number of visitors to the area. The net impact of alien removal and fynbos restoration on carbon sequestration is also disregarded owing to the assumption that the change in the amount of carbon sequestered will be insufficient to allow for cost-effective carbon trading. The water released is assumed to be of adequate quality for consumption. Non-use existence values were not included in the model due to the focus on using marketable ecosystem goods and services to justify clearing and restoration costs.

\subsection{Model description}

The value of alien removal and fynbos restoration at a systems level $\left(V_{t}\right)$ for year $t$ is a function of the annual change in income from fynbos products $\left(I_{t}\right)$, water supply $\left(W_{t}\right)$, beekeeping $\left(B_{t}\right)$, the supply of woody biomass $\left(M_{t}\right)$, and clearing and restoration costs $\left(C_{t}\right)$.

$V_{t}=f\left(I_{t}, W_{t}, B_{t}, M_{t}, C_{t}\right)$

The direct benefits that the fynbos ecosystem generates through focal Proteacea flowers and cones, foliage and greens used in flower arrangements, and other fynbos products such as thatching reed and honeybush is captured using net income at farm gate for each fynbos vegetation type (Turpie, Heydenrych \& Hassan, 2002). Farmers in South Africa are not supported by formal subsidies, suggesting that this value estimate can be regarded as an efficient price. The study distinguishes between invaded land that has been transformed by agriculture and development, and invaded natural veld. As expected, invasive vegetation has occupied natural veld to a greater extent than veld under alternative land use. It assumes that wildflowers, foliage and greens, thatching reed and honeybush will be harvested from invaded marginal agricultural land from which farmers receive no direct income, and not from invaded veld. This accommodates for the fact that the latter may be classified as protected or public areas from which no harvesting is allowed.

Different types of fynbos vegetation types yield varying supplies of wildflowers and fynbos products. It is assumed that the appropriate species are sown during the restoration process to allow wildflowers, honeybush and thatching reed to be harvested from restored areas. To estimate the annual change in net income from wildflowers, a veld age productivity factor that changes as the plants mature is used (Bailey, Euston-Brown \& Privett, 2007). Honeybush harvests are assumed to start in the second year after restoration at an annual net income of R19.20 per hectare (Turpie et al., 2002; Agricultural Research Council, 2012). Thatching reed generates a net income of R39.67 per hectare (Turpie et al., 2002), with harvesting assumed to start four years after restoration (Jamieson, 2001; Linder, 1990).

Sour fig harvesting often takes place without the consent of landowners, but as a marketable product provided by the fynbos ecosystem it is included as a benefit in this study. Annual net income derived from sour fig harvesting is estimated as R17.90 per hectare (Heydenrych, 1999). The study assumes that sour fig harvesting could take place from all restored Strandveld fynbos and as a fast grower is available for harvesting one year after restoration (Malan \& Notten, 2006). Condensed hectares of different fynbos vegetation types are used to estimate the change in net income at a systems level.

Direct project costs incurred by alien clearing and fynbos restoration is composed of the cost of initial clearing, the cost of restoration, and the cost of five follow-up clearings. Restoration costs include seed collection, seed preparation and sowing. It is assumed that initial clearing and restoration treatments are completed during the first year, and that follow-up clearings are completed consecutively during the next five years.

The model uses cost estimates of clearing high density invasion to estimate the cost of clearing the number of condensed invaded hectares on the Agulhas Plain (Marais \& Wannenburgh, 2008). A hypothetical cost per hectare is calculated based on the proportion of total invasion of each of the invasive species included in the study.

The financial net present value $\left(N P V^{f}\right)$ estimates whether it is profitable for landowners to clear and restore their land, derived from the change in net income from wildflowers and other fynbos products (equation 2). Sour figs 
are excluded from this estimation since income from sour fig harvesting is not incurred by landowners. The discount rate is $r$.

$N P V^{f}=C_{0}+\sum_{t=1}^{20} \frac{\left(I_{t}-C_{t}\right)}{(1+r)^{t}}$

The economic net present value incorporates into the equation the change in the supply of sour figs, the beekeeping industry, the supply of fuel wood and water. Fynbos vegetation holds foraging value for bees, while Eucalyptus forests provide pollination services that will be foregone if the trees are removed. The change in the value of honey production is based on the difference between net income at farm gate per fynbos vegetation type and the total value of pollination services provided by Eucalyptus forests on the Agulhas Plain, as estimated by Heydenrych (1999). If $B_{t}>0$, clearing and restoration will add value to the beekeeping and honey production industry, but if $B_{t}<0$, an opportunity cost is implied. Bees do not restrict their behaviour to farm boundaries and estimates are based on the total number of condensed invaded hectares on the Plain.

The removal of invasive trees on the Agulhas Plain implies an opportunity cost to many of the rural households. The study assumes that landowners receive no rent from invaded land, leaving the opportunity cost of fuel wood to be estimated as the average net income per hectare that rural households derive from harvesting fuel wood from densely invaded vegetation (Turpie et al., 2003). This value is extrapolated across condensed hectares of Acacia Cyclops invasion in Strandveld and Lime fynbos.

Invasive vegetation interferes with aquifers by making demands on groundwater and decreasing the amount of rainwater available to replenish the water table (Le Maitre et al., 1999). In the Western Cape, alien species account for using 15.82 per cent of the mean annual water runoff (Le Maitre et al., 2000). A lower incidence of invasive vegetation will lead to a decrease in evapotranspiration and ultimately to an increase in the supply of groundwater and surface water available. Alien clearing and restoration on the Agulhas Plain will release an estimated $82264050 \mathrm{kl}$ of water into the hydrological system (Nowell, 2010).
The fraction of the total water released by alien clearing that will be made available as runoff and that can be collected for consumption is unclear. In addition, no studies specific to the Agulhas Plain provide estimates of the average value of water for different industries. This study opts to estimate the average value of water $\left(p_{i}\right)$ required to justify alien clearing and restoration at a systems level under different runoff scenarios $\left(y_{i}\right)$ (equation 3 ). The use of average value instead of the marginal value of water is based on the assumption of constant returns to scale and price-taking by consumers.

$p_{i}=\frac{C_{0}+\sum_{t=1}^{20} \frac{C_{t}+B_{t}+M_{t}-I_{t}}{(1+r)^{t}}}{\sum_{t=1}^{20} \frac{82264050\left(y_{i}\right)}{(1+r)^{t}}}$

\section{5}

\section{Results}

\subsection{Ecosystem goods and services}

The change in annual net income from wildflowers and other fynbos products harvested from the restored areas on the Agulhas Plain will range from R0.4 million to R1.3 million. Figure 4 illustrates that Proteacea flowers and cones from Mountain fynbos, and sour fig harvests from Strandveld fynbos hold the greatest potential for generating income.

Total clearing and restoration costs amount to R176 million, of which the restoration component comprises 21 per cent. The costs incurred during the first year account for 72 per cent of total direct costs.

As an indirect cost, the pollination services that Eucalyptus forests provide for beekeeping outweighs the foraging value of indigenous fynbos. This suggests that an annual opportunity cost of R1.37 million to the beekeeping industry will occur if all Eucalyptus forests are removed from the Plain. The additional opportunity cost of fuel wood due to the removal of Acacia Cyclops will amount to R4.31 million. Table 1 lists the range of different direct and indirect cost and benefit components. 
Figure 4

Direct net income from fynbos products at a system level

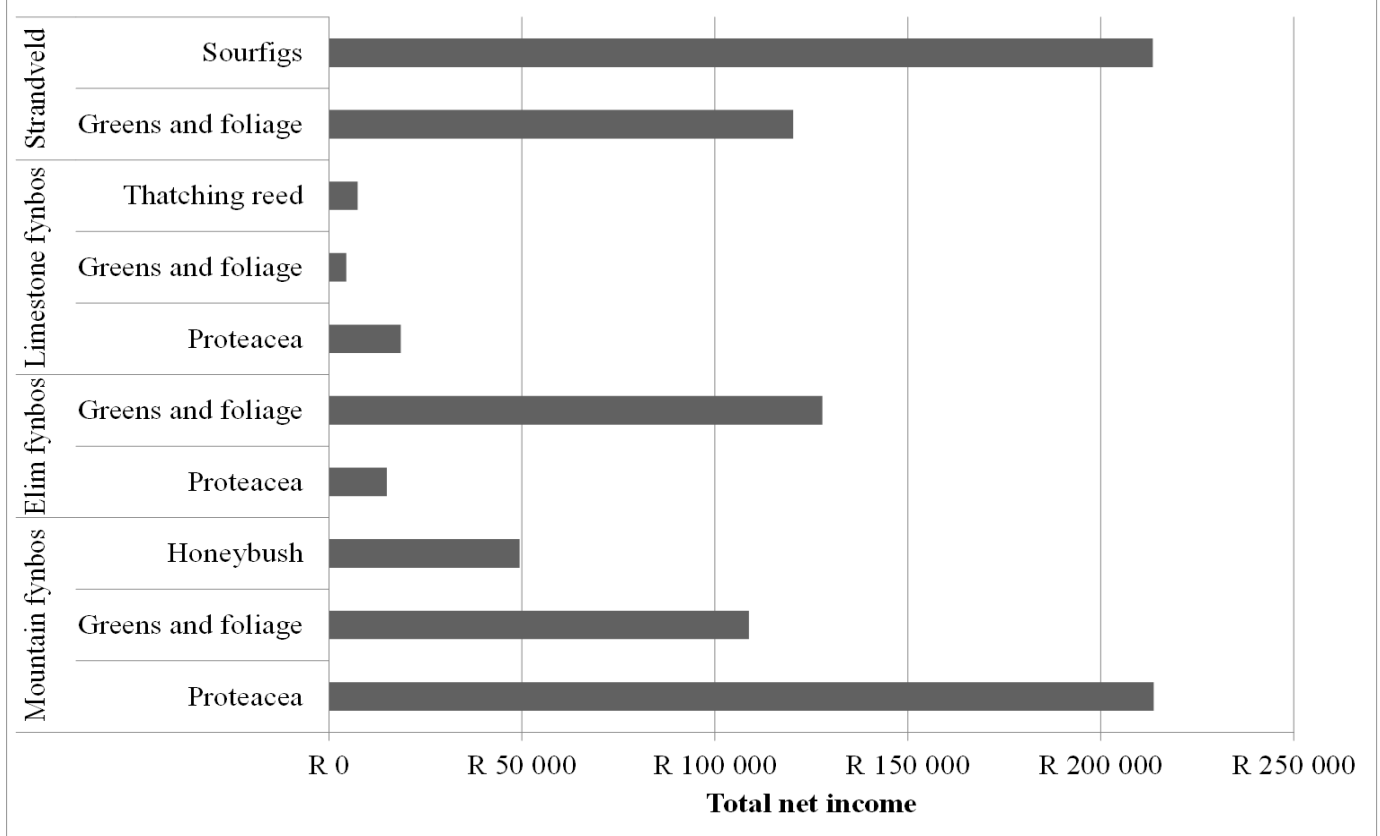

Table 1

Direct and indirect costs and benefits; Million Rand

\begin{tabular}{|c|c|c|c|c|}
\hline \multirow{2}{*}{ Benefit/Cost components } & \multirow{2}{*}{$\begin{array}{l}\text { Annual average over } \\
20 \text { years }\end{array}$} & \multicolumn{3}{|c|}{ Net present value } \\
\hline & & $3 \%$ & $8 \%$ & $12 \%$ \\
\hline \multicolumn{5}{|l|}{ Direct costs and benefits } \\
\hline Income from wildflowers and other fynbos products & R 0.92 & R 13.48 & R 8.48 & R 6.13 \\
\hline Clearing and restoration costs & $-R 9.86$ & -R 194.67 & $-\mathrm{R} 190.83$ & $-\mathrm{R} 188.14$ \\
\hline \multicolumn{5}{|l|}{ Indirect costs } \\
\hline Fuel wood & $-R 4.31$ & $-\mathrm{R} 64.05$ & $-\mathrm{R} 42.27$ & $-\mathrm{R} 32.16$ \\
\hline Beekeeping and honey production & $-R 1.37$ & $-\mathrm{R} 20.33$ & -R 13.41 & $-\mathrm{R} 10.21$ \\
\hline
\end{tabular}

\subsection{Cost-benefit analyses}

The financial net present value of clearing invasive vegetation and restoring natural capital on the Agulhas Plain ranges between -R183.5 million and -R184.5 million at the system level, depending on the discount rate assumed. This indicates that an investment to clear the entire Agulhas Plain of invasive species and restore natural fynbos vegetation will not be offset by the additional direct income that can be generated from harvesting fynbos flowers and other fynbos products.

When the impact on beekeeping, honey production and the opportunity cost of fuel wood is added, the economic net present value yields a negative return of between R224 million and R265 million.

The results suggest that the water released through clearing and restoration needs to be an economically valued commodity in order to ensure a cost-effective outcome. The availability and cost of alternative water sources determines whether the cost at which water can be made available through alien clearing and restoration is low enough to justify investment. Figure 5 summarises the outcome of equation 3 by illustrating the average value of water that will justify clearing and restoration under different discount rates in relation to runoff, and compares these values to existing costs of water on the Agulhas Plain. 
Figure 5

Average water value that will justify clearing and restoration costs under hypothetical runoff scenarios

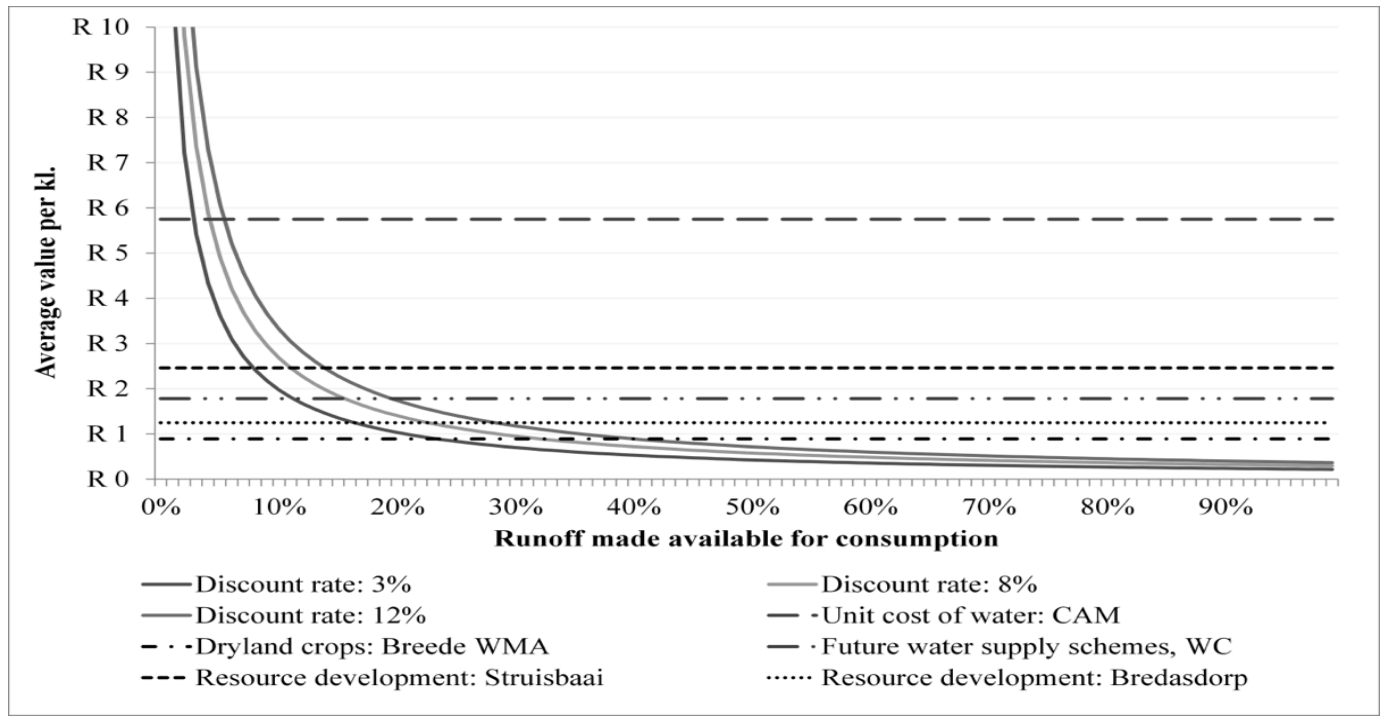

The Cape Agulhas Municipality (CAM), in which the Agulhas Plain is primarily located, abstracts more than half of its water from production boreholes. An estimated 1896437 $\mathrm{kl}$ of water was supplied to towns on the Agulhas Plain during 2007/08, equivalent to 2.3 per cent of the total amount of water that is projected to be released through alien clearing. The CAM calculates the unit cost of water (water supply divided by operating costs) at R5.75 per kilolitre. This estimate includes personnel expenses, repair and maintenance costs and capital expenditure and is not an accurate reflection of the value of water in the area, but it does provide an average upper estimate of what the municipality is willing to pay for water supply. At this upper estimate of water value, 3-6 per cent of water released by alien clearing and restoration will have to be provided as consumable runoff in order for such a project to be efficient.

In 2001/02, the Municipality had a budget of R0.35 million for the development of water resources in Struisbaai. Potential boreholes in the area were estimated at being able to yield an additional $208050 \mathrm{kl}$ per annum (Overberg District Municipality, 2003). This amounts to a cost of R2.46 per kilolitre, and suggests that alien clearing and restoration could provide a lower cost alternative if more than 10-14 per cent of water released is made available as runoff in the area. A similar approach for water resource development in Bredasdorp provides a cost estimate of R1.25 per kilolitre (Cape Agulhas Municipality, 2009), where 15-28 per cent of water released will have to be made available to ensure an efficient outcome.

In accordance with Turpie et al. (2003), a comparable value for the cost of water supply is provided by the average capital and operational costs of future water supply schemes in the Western Cape. Burgers, Marais and Bekker (1995) estimate this to be R1.78 per kilolitre. Our results suggest that at consumable runoff of more than 13-20 per cent of water released through alien clearing, the latter will provide a lower-cost alternative for augmenting water supply.

Dry land crop production accounts for a large proportion of land use on the Agulhas Plain. In South Africa the National Water Accounts are increasingly regarded as one of the more accurate estimates of the average value of water per land use type (Turpie, 2004). The Accounts do not disaggregate water use by local municipality, but estimate that in the Breede Water Management Area (WMA) in which the Agulhas Plain is located - R0.89 worth of dryland crops is produced per kilolitre of water used in dryland agriculture (Statistics 
South Africa, 2009). Assuming that dryland production practices on the Agulhas Plain are similar to the rest of the Breede WMA, at least 23-40 per cent of water released through alien clearing and restoration will have to be made available for dryland crops on the Plain in order to justify the investment.

Past water scarcity on the Agulhas Plain was addressed by building dams or drilling boreholes (Cape Agulhas Municipality, 2009). This study suggests that, depending on the value of water in the Agulhas Plain, alien clearing and restoration can provide a positive return if 3-40 per cent of the water released is made available for consumption (illustrated in Figure 5). As climate change progresses and the area becomes even more water scarce, clearing and restoration will become costeffective at lower quantities of runoff.

\section{6}

\section{Conclusions and recommendations}

Growing human societies and impending climate change is threatening the sustainable supply of ecosystem goods and services. Invasive vegetation poses an additional threat to the goods and services supplied by indigenous ecosystems. This study tests the hypothesis that alien removal and natural capital restoration may add value to invaded areas through recovering the ecosystem goods and services supplied by indigenous vegetation. It draws from ecological, hydrological and economic observations to assess the net impact that alien removal and restoration could have in the Agulhas Plain.

The results unequivocally show that the cost of clearing the entire Agulhas Plain of invasive vegetation and restoring indigenous fynbos to invaded areas cannot be justified solely based on direct financial benefits. The results further illustrate that in the absence of water as an economically valued commodity, other indirect economic impacts are unable to justify invest- ment. Preliminary appraisals of the value of water under different runoff scenarios suggest that water at a systems level is sufficiently valued to provide an efficient outcome for clearing and restoration projects on the Agulhas Plain. However, it is important to note that runoff and water values are industry and area specific. While the results indicate that alien clearing and restoration could be justified at a systems level, investment decisions should be preceded by an investigation into area specific runoff and water demand.

Payments for ecosystem services can be used as an instrument to encourage alien clearing and restoration activities. Local municipalities on the Agulhas Plain could offer landowners payments to clear and restore their land in exchange for a proportion of the water made available. In this way farming income can be augmented to the extent that it renders alien clearing and restoration financially feasible for landowners, while at the same time providing municipalities with a lower cost alternative of water supply. Alternatively, municipalities can decide to undertake clearing activities themselves in return for a proportion of the water made available, leaving landowners responsible to restore cleared land. Irrespective of the strategy adopted, payments must be designed in a way that ensures that landowners will continue to keep their land free of invasive alien vegetation. Payments would have to compensate the gap between direct project costs and improved land use.

With the rising economic value of water induced by climate change and growing demand, it is expected that alien clearing and restoration will increasingly become an economically viable land and ecosystems management strategy, and payments for ecosystem goods and services an efficient instrument with which such activities can be encouraged.

\section{Endnote}

Study coordinated by ASSET Research and funded by the Water Research Commission (Project K5/1803).

\section{Acknowledgements}

We are grateful to the Water Research Commission (WRC) - Key Strategic Area, Water Utilisation in Agriculture (KSA4) who commissioned and funded this study. The work forms part of the broader WRC project entitled, 'The impact of re-establishing indigenous plants and restoring the natural landscape on sustainable rural employment and land productivity through payment for environmental services'. 
The authors would also like to extend a word of thanks to individuals who provided comments upon the presentation of previous versions of this paper.

\section{References}

AGRICULTURAL RESEARCH COUNCIL. 2012. ARC Honeybush research programme: botanical information. Available at: http://www.arc.agric.za/home.asp?pid=4053 [accessed 2012-06-04].

AYLWARD, B. \& BARBIER, E.B. 1992. Valuing environmental functions in developing countries. Biodiversity and Conservation, 1:34-50.

BAILEY, R., EUSTON-BROWN, D. \& PRIVETT, S. 2007. Resource base assessment of wild fynbos plants on Waterford Farm, Agulhas Plain: a pilot study. Flower Valley Conservation Trust \& the Agulhas Biodiversity Initiative.

BENCKE, J.D. 1908. Port Jackson willow as a Sluit Stopper. The Agricultural Journal, 32:652.

BLIGNAUT, J.N. \& LUMBY, A. 2004. Economic valuation. In: Blignaut, J. \& De Wit, M. P. (eds.) Sustainable options. Cape Town: UCT Press.

BLIGNAUT, J.N. \& DE WIT, M. 2004. The economics of the environment. In: Blignaut, J. \& De Wit, M. (eds.) Sustainable options. Cape Town: UCT Press.

BRIGHT, C. 1999. Invasive species: pathogens of globalization. Foreign Policy, 116:50-64.

BURGERS, C.J., MARAIS, C. \& BEKKER, S.J. 1995. The importance of mountain catchments for maintaining the water resources of the Western Cape Province and the need for optimal management. In: Boucher, C. \& Marais, C. (eds.) Managing fynbos catchments for water. FRD Programmes Report. BUTCHART, S.H.M., CHANSON, J. \& HOFFMANN, M. 2009. Red list indices for invasive species' impacts. Technical Report for the global invasive species programme. Birdlife International, Washington DC, USA.

CAPE AGULHAS MUNICIPALITY. 2009. Cape Agulhas Municipality Water Services Development Plan 2007/8-2011/12.

CAREY, A. 2007. Restoring and maintaining natural capital in the Pacific Northwest, USA. In: Aronson, J., Milton, S.J. \& Blignaut, J.N. (eds.) Restoring Natural Capital: Science, Business and Practice. Washington DC: Island Press.

CHIESURA, A. \& GROOT, R.D. 2003. Critical natural capital: a socio-cultural perspective. Ecological Economics, 44:219-231.

COLE, N.S., LOMBARD, A.T., COWLING, R.M., EUSTON-BROWN, D., RICHARDSON, D.M. \& HEIJNIS, C.E. 2000. Framework for a conservation plan for the Agulhas Plain, Cape Floristic Region, South Africa. Institute for Plant Conservation Report. Cape Town: University of Cape Town.

CONRADIE, B. 2010. Farmers' views of landscape initiatives: The case of the Agulhas Plain, CFR. CSSR Working Paper, 278:1-70.

CONRADIE, B. \& KNOESEN, H. 2009. A survey of cultivation and wildflower harvesting of fynbos flowers in South Africa. PPSA Nuusbrief, July.

COWLING, R.M. \& HOLMES, P.M. 1992. Flora and vegetation. In: Cowling, R.M. (ed.) The ecology of fynbos: nutrients, fire and diversity. Cape Town: Oxford University Press.

CURRIE, B., MILTON, S. \& STEENEKAMP, J.C. 2009. Cost-benefit analysis of alien vegetation clearing for water yield and tourism in a mountain catchment in the Western Cape of South Africa. Ecological Economics, 68:2574-2579.

DALY, H. 1994. Operationalising sustainable development by investing in natural capital. In: Jansson, A.M., Hammer, M., Folke, C. \& Costanza, R. (eds.) Investing in natural capital: the ecological economics approach to sustainability. Washington DC: Island Press.

DE WIT, M.P., CROOKES, D.J. \& VAN WILGEN, B.W. 2001. Conflicts of interest in environmental management: estimating the costs and benefits of a tree invasion. Biological Invasions, 3:167-178.

GROVES, R.H. 1989. Ecological control of invasive terrestrial plants. In: Drake, J.A. (ed.) Biological invasions: a global perspective. John Wiley \& Sons Ltd.

HENDERSON, L. 2007. Invasive, naturalized and casual alien plants in southern Africa: a summary based on the Southern African Plant Invaders Atlas (SAPIA). Bothalia, 37:215-248. 
HEYDENRYCH, B.J. 1999. Historical background of land use on the Agulhas Plain. `1 Flower Valley Farm (ed.).

HIGGENS, S.I., TURPIE, J.K., COSTANZA, R., COWLING, R.M., LE MAITRE, D.C., MARAIS, C. \& MIDGLEY, G.F. 1997. An ecological economic simulation model of mountain fynbos ecosystems:

Dynamics, valuation and management. Ecological Economics, 22:155-169.

JAMIESON, H. 2001. Thamnochortus insignis (Mast.). Available at: http://www.plantzafrica.com/planttuv/ thamnocortinsig.htm [accessed 2012-06-04].

LE MAITRE, D.C., SCOTT, D.F. \& COLVIN, C. 1999. A review of interaction between vegetation and groundwater. Water SA, 25:137-152.

LE MAITRE, D.C., VAN WILGEN, B.W., CHAPMAN, R.A. \& MCKELLY, D.H. 1996. Invasive plants and water resources in the Western Cape Province: modelling the consequences of a lack of management. Journal of Applied Ecology, 33:161-172.

LE MAITRE, D.C., VERSFELD, D.B. \& CHAPMAN, R.A. 2000. The impact of alien plants on surface water resources in South Africa: a preliminary assessment. Water SA, 26:397-408.

LEVINE, J.M. \& D'ANTONIO, C.M. 2003. Forecasting biological invasions with increasing international trade. Conservation Biology, 17:322-326.

LINDER, H. P. 1990. The thatching reed of Albertinia. Veld and Flora, September:86-89.

LOOMIS, J., KENT, P., STRANGE, L., FRASER, K. \& COVICH, A. 2000. Measuring the total economics value of restoring ecosystem services in an impaired river basin: results from a contingent valuation survey. Ecological Economics, 33:103-117.

LOW, A.B. \& REBELO, A.G. 1996. Vegetation of South Africa, Lesotho and Swaziland. Pretoria, Department of Environmental Affairs and Tourism.

MALAN, C. \& NOTTEN, A. 2006. Carpobrotus edulis. Available at: http://www.plantzafrica.com/ plantcd/carpobed.htm [accessed 2012-06-04].

MARAIS, C. \& WANNENBURGH, A.M. 2008. Restoration of water resources (natural capital) through the clearing of invasive alien plants from riparian areas in South Africa: Costs and water benefits. South African Journal of Botany, 74:526-537.

MOONEY, H.A. \& CLELAND, E.E. 2001. The evolutionary impact of invasive species. PNAS, 98:54465451.

MULLINS, D., MOSAKA, D.D., GREEN, A.B., DOWNING, R. \& MAPEKULA, P.G. 2007. A manual for cost benefit analysis in South Africa with specific reference to water resource development. Water Research Commission Report, 305/07.

MYERS, N. 1990. The biodiversity challenge: expended hotspot analysis. The Environmentalist, 10:243-255. NOWELL, M. 2010. Determining the hydrological benefits of clearing invasive alien plants on the Agulhas Plain. MSc, University of Stellenbosch.

OVERBERG DISTRICT MUNICIPALITY 2003. Water Services development plan: Cape Agulhas municipality. Draft 1, Volume 1:1-98.

PERRINGS, C., MOONEY, H.A. \& WILLIAMSON, M.H. 2010. The problem of biological invasion In: Perrings, C., Mooney, H. A. \& Williamson, M. H. (eds.) Bioinvasions and globalization: ecology, economics, management and policy. New York: Oxford University Press.

PERRINGS, C., WILLIAMSON, M., BARBIER, E.B., DELFINO, D., SILVANA, D., SHOGREN, J., SIMMONS, P. \& WATKINSON, A. 2002. Biological invasion risks and the public good: an economic perspective. Conservation Ecology, 6.

RICHARDSON, D.M. 1998. Ecology and biogeography of Pinus. Cambridge: Cambridge University Press. RICHARDSON, D.M., MACDONALD, I.A.W., HOFFMAN, J.H. \& HENDERSON, L. 1997. Alien plant invasions. In: Cowling, R. M., Richardson, D. M. \& Pearce, S. M. (eds.) Vegetation of Southern Africa. Cambridge: Cambridge University Press.

RICKETTS, T.H., DAILY, G.C., EHRLICH, P.R. \& MICHENER, C.D. 2004. Economic value of tropical forest to coffee production. PNAS, 101:12579-12582.

ROUGET, M. 2003. Measuring conservation value at fine and broad scales: implications for a diverse and fragmented region, the Agulhas Plain. Biological Conservation, 112:217-232. 
STATISTICS SOUTH AFRICA. 2009. National Accounts: Water Accounts for South Africa. Discussion Document. Pretoria.

TURPIE, J. 2004. The role of resource economics in the control of invasive alien plants in South Africa. South African Journal of Science, 100:87-93.

TURPIE, J., HEYDENRYCH, B.J. \& HASSAN, R. 2002. Fynbos: A preliminary assessment of its status and economic value. In: Hassan, R. (ed.) Accounting for stock and flow values of woody land resources.

TURPIE, J., HEYDENRYCH, B.J. \& LAMBERTH, S.J. 2003. Economic value of terrestrial and marine biodiversity in the Cape Floristic Region. Biological Conservation, 112:233-251.

VAN WILGEN, B.W., COWLING, R.M. \& BURGERS, C.J. 1996. Valuation of ecosystem services. BioScience, 46:184-189.

WILCOVE, D.S., ROTHSTEIN, D., DUBOW, D., PHILLIPS, A. \& LOSOS, E. 1998. Quantifying threats to imperiled species in the United States. BioScience, 48:607-615. 